\title{
APLIKASI PEMBELAJARAN TAPPS DALAM PENINGKATAN HASIL BELAJAR STRUKTUREN UND WORTSCHATZ MAHASISWA PROGRAM STUDI PENDIDIKAN BAHASA JERMAN
}

\author{
Samuel Jusuf Litualy \\ Fakultas Keguruan dan Ilmu Pendidikan, Universitas Pattimura, Ambon \\ email:
}

\begin{abstract}
Abstrak. Tipe penelitian kuasi eksperimen ini dilaksanakan dengan tujuan untuk membuktikan peningkatan hasil belajar Strukturen und Wortschatz 2 mahasiswa dengan aplikasi metode kooperatif model TAPPS, danpengaruh penerapan model tersebut terhadap peningkatan motivasi belajar mahasiswa Program Studi Pendidikan Bahasa Jerman. Variabel-variabel dalam penelitian ini, adalah: hasil belajar mahasiswa dalam Strukturen und Wortschatz 2 (variabel terikat), dan model kooperatif tipe TAPPS (variabel bebas). Sampel penelitian ini adalah mahasiswa program studi pendidikan bahasa Jerman semester II dengan responden sebanyak 32 orang. Instrumen penelitian ini adalah materi tes (Pretest dan Posttest). Dari data yang dianalisis, diperoleh nilai $\mathrm{t}_{\text {hitung }}=32,025$ dengan $\mathrm{t}_{\text {tabel }}$ pada taraf signifikan á $=0,05 \mathrm{dan} \mathrm{dk}=30$ diperoleh $\mathrm{t}_{\text {tabel }}=0,00$. Ini menunjukkan bahwa $\mathrm{t}_{\text {hitung }}>\mathrm{t}_{\text {tabel }}\left(\mathrm{t}_{\text {hitung }}=32,025>\right.$ probability $\left.=0,00\right)$. Dari hasil tersebut, dapat disimpulkan bahwa Hasil Belajar Strukturen und Wortschatz 2 mahasiswa dengan aplikasi Metode Kooperatif Model TAPPS lebih tinggi dari Hasil Belajar Strukturen und Wortschatz 2 mahasiswa tanpa aplikasi Metode Kooperatif Model TAPPS.
\end{abstract}

Kata kunci: Hasil belajar Strukturen und Wortschatz, 2, model pembelajaran kooperatif tipe TAPPS

\section{THE APPLICATION OF TAPPS LEARNING PROCESS IN IMPROVING LEARNING OUTCOME OF STUKTUREN UND WORTSCHATZ COURSE ON GERMAN LANGUAGE EDUCATION PROGRAM' STUDENTS.}

\begin{abstract}
This Quasi Experimental Research was conducted to prove how the increase of students' outcomes in learning Strukturen und Wortschatz with the application of cooperative learning model of TAPPS method, and how the influence of these applications increase learning motivation in second semester students of the German Language Education Program, Educational Science and Teacher Training Faculty, Pattimura University, in the Academic Year 2015/2016. Variables of this research were student learning outcomes in learning Strukturen und Wortschatz 2 (the dependent variable) and TAPPS learning method (independent variable). Samples of this research are second semester students of the German Language Education Program in the Academic Year 2015/2016, with 32 respondents. Research instrument for this study is the test material (Pre-test and post-test). Based on the outcomes of data analysis, the value of $\mathrm{t}_{\text {obtained }}=32.025$ with $\mathrm{t}_{\text {distribution }}$ at significance $\mathrm{a}=0.05$ and $\mathrm{dk}=30$, which is obtained from $\mathrm{t}_{\text {distribution }}=0.00$. The result shows that $t_{\text {obtained }}>t_{\text {distribution }}(t=32.025$, > probability $=0.00)$. Based on these outcomes, it can be concluded that the learning outcome of Strukturen und Wortschatz 2 from the students of German Language Education Program who are taught with Cooperative Learning Model of TAPPS method is higher than those students who are taught without Cooperative Learning Model of TAPPS method.
\end{abstract}

Key words: Learning outcomes of Strukturen und Wortschatz, 2, TAPPS model of cooperative learning methods

\section{PENDAHULUAN}

Dalam pelaksanaan proses belajar dan mengajar, tenaga pengajar (Dosen) memiliki peran yang sangat penting dalam menentukan kuantitas dan teristimewa kualitasnya, sebab menurut Tilaar (2006:36) kualitas sebagai inti dari standardisasi (khususnya dalam dunia pendidikan). Untuk itu, dosen harus memikirkan dan merencanakan pembelajaran secara seksama dalam rangka meningkatkan kualitas belajar bagi mahasiswanya dan tentu saja harus mengembangkan kualitas mengajarnya. 
Berkaitan dengan hal ini terdapat tuntutan agar terjadi perubahan-perubahan dalam pengorganisasian kelas, penggunaan metode mengajar, strategi belajar-mengajar, maupun sikap dan karakteristik dosen dalam mengelola proses belajar-mengajar. Selaku administrator, dosen dituntut untuk terus berusaha menciptakan kondisi belajar yang efektif sehingga memungkinkan proses belajar-mengajar berjalan dengan baik dan lancar, selain itu dosen juga dituntut untuk terus mengembangkan bahan pelajaran yang lebih baik, dan berusaha meningkatkan kemampuan mahasiswa dalam memahami pelajaran dan menguasai tujuan-tujuan pembelajaran yang harus mereka capai.

Untuk memenuhi hal tersebut di atas dosen diharapkan mampu mengelola proses belajarmengajar yang terus menerus memberikan rangsangan kepada mahasiswa sehingga mereka berniat belajar karena mahasiswa merupakan subjek utama dalam proses belajar mengajar. Dosen juga diharapkan dapat menciptakan kondisi belajar-mengajar yang nyaman dan efektif, yang memungkinkan adanya partisipasi aktif dari semua mahasiswa, terutama dalam pembelajaran bahasa Jerman.

Sebagai alat komunikasi bahasa Jerman berfungsi untuk mengembangkan kemampuan berpikir dan bernalar mahasiswa, selain itu bahasa Jerman juga sebagai alat komunikasi dalam menjelaskan gagasan.

Pembelajaran Bahasa Jerman tidak lagi mengutamakan pada pemahaman melalui pencapaian informasi, tetapi lebih mengutamakan pada pengembangan kemampuan dan pemrosesan informasi. Untuk itu aktivitas peserta didik perlu ditingkatkan melalui latihan-latihan seperti pengerjaan tugas-tugas bahasa Jerman dalam kelompok kecil dan penjelasan ide-ide kepada sesama mahasiswa yang lain, sebab keterlibatan mahasiswa (peserta didik) dalam proses belajar adalah "jantung" dari proses belajar yang efektif(Megawangi dkk. (2005:43). Langkah-langkah tersebut memerlukan partisipasi aktif dan motivasi yang tinggi dari semua mahasiswa. Dalam hubungan dengan hal ini, maka diperlukan metode pembelajaran yang melibatkan mahasiswa secara langsung dalam pembelajaran. Model pembelajaran yang diharapkan mampu mewujudkan langkah-langkah di atas adalah model pembelajaran kooperatif tipe TAPPS. Pembelajaran kooperatif adalah suatu model pengajaran yang melibatkan mahasiswa bekerja dalam kelompok-kelompok untuk mencapai tujuan bersama (Felder, 1994:2).

Pembelajaran kooperatif lebih menekankan pada interaksi antar mahasiswa. Melalui model pembelajaran ini mahasiswa akan dapat mengimplementasikan komunikasi aktif dengan sesamanya. Dengan adanya komunikasi tersebut diharapkan mahasiswa dapat menguasai materi pelajaran dengan mudah karena "mahasiswa lebih mudah memahami penjelasan teman-teman bila dibandingkan dengan penjelasan dari dosen karena taraf pengetahuan serta pemikiran mereka lebih sejalan dan sepadan" (Sulaiman dalam Wahyuni 2001:2). Pelaksanaan penelitian ini bertujuan bertujuan untuk memperoleh pembuktian yang menggambarkan bahwa pembelajaran kooperatif memiliki dampak yang lebih positif terhadap mahasiswa dengan hasil belajarnya yang rendah. (Nur, 1996:2).

Dalam kaitan ini, pembelajaran Strukturen und Wortschatz adalah proses belajar yang dilakukan dalam upaya memberikan kesempatan kepada mahasiswa untuk memahami dan menguasai, kaidah-kaidah gramatika atau tata bahasa bahasa Jerman serta mempraktekkannya dalam situasi nyata. Khusus untuk Strukturen und Wortschatz 2, materi-materi pembelajaran meliputi: (1) Nebensätze mit weil, dass, (2), Komparation mit wie und als (3) Reflexivpronomen, (4) Verben mit Präpositionen, (5) Indirekte Fragen im Nebensatz: ob-Sätze / indirekte W-Fragen, Adjektive im Nominativ und Akkusativ, (6) Personalpronomen im Dativ: mit dir, mit ihm, (7) Relativsatz, Relativpronomen im Nominativ und Akkusativ, (8) Modalverben im Präteritum, (9) Zeitadverbien: damals, früher, heute, jetzt, (10) Verben im Präteritum, (11) Verben im Perfekt, (12) Nominalisierung, (13) Wechselpräpositionen, und (14) Nebensätze mit um - zu/damit (Funk, dkk, 2008).

Melalui pembelajaran Strukturen und Wortschatz bahasa Jerman mahasiswa diharapkan mampu belajar Grammatik bahasa Jerman dengan berbagai cara yang sangat bermakna, seperti belajar secara sistematis dengan langkah-langkah penyajian yang bervariasi untuk membangkitkan minat dan motivasi mahasiswa, baik dalam bentuk permainan, maupun dengan dialog-dialog, dan diikuti dengan kerjasama antar mahasiswa maupun kelompok mahasiswa yang membangun, sehingga memperoleh hasil pembelajaran yang efektif dan bermutu dapat diperoleh (Frangou, Eleni, dkk. 2014). 
Hasil yang ingin dicapai dalam penelitian ini adalah untuk mengetahui bagaimana terjadi peningkatan hasil belajar dalam pembelajaran Strukturen und Wortschatz dengan diterapkannya model pembelajaran kooperatif tipe TAPPS pada mahasiswa Program Studi Pendidikan Bahasa Jerman. Selain itu, penelitian ini bertujuan juga untuk mengetahui pengaruh penerapan model pembelajaran kooperatif tipe TAPPS terhadap motivasi belajar mahasiswa Program Studi Pendidikan Bahasa Jerman.

\section{METODE}

Penelitian ini merupakan tipe penelitian kuasi eksperimen, dimana perlakuan atau eksperimen hanya dilaksanakan pada satu kelompok tanpa kelompok pembanding. Penelitian ini dilaksanakan dengan tujuan untuk membuktikan ada atau tidak adanya pengaruh penerapan model pembelajaran kooperatif tipe TAPPS sebagai upaya meningkatkan hasil belajar Strukturen und Wortschatz 2 pada Mahasiswa Program Studi Pendidikan Bahasa Jerman FKIP Unpatti semester 2 tahun akademik 2015/2016 dengan menggunakan dua kelompok, dimana kelompok $\mathrm{X}_{1}$ menggunakan pembelajaran konvensional dan kelompok $\mathrm{X}_{2}$ menggunakan model kooperatif tipe TAPPS. Ada dua variabel, yang diuji, yaitu (a) variabel terikat: hasil belajar mahasiswa dalam pembelajaran Strukturen und Wortschatz 2, dan (b) variabel bebas: model pembelajaran kooperatif tipe TAPPS.

Populasi penelitian meliputi seluruh mahasiswa Program Studi Pendidikan Bahasa Jerman, dan sampel penelitian ini adalah mahasiswa program studi pendidikan Bahasa Jerman semester II tahun akademik 2015/2016, atau tepatnya mahasiswa yang mengambil mata kuliah Stukturen und Wortschatz 2, dengan jumlah responden sebanyak 64 orang dengan dua kelompok, masing-masing berjumlah 32 orang. Instrumen penelitian yang digunakan dalam penelitian ini adalah instrument tes (Pretest dan Posttest). Pretes dilaksanakan sebelum perlakuan diberikan, yakni; penerapan model pembelajaran kooperatif tipe TAPPS, sedangkan post-test dilaksanakan setelah perlakuan diberikan dengan penerapan model pembelajaran kooperatif tipe TAPPS. Bentuk tes yang digunakan adalah tes tulisan objektif dengan masingmasing butir soal memiliki lima pilihan. Tes disusun berdasarkan tujuan pembelajaran yang akan dicapai dan digunakan untuk mengukur kemampuan pemahaman materi Strukturen und Wortschatz 2.

Untuk menjaga tingkat kevalidan tes, nilai akhir setiap peserta telah dibandingkan dengan nilai-nilai ujian mereka dengan mata kuliah, yang telah mereka ikuti, seperti: Hörverständnis 2, Sprechfertigkeit 2, dan Leseverständnis 2, yang tidak menunjukkan perbedaan yang menyolok karena salah satu cara untuk menentukan valid/ tidaknya tes digunakan adalah dengan membandingkan nilai yang diperoleh mahasiswa dengan nilai-nilai yang pernah diperoleh (Rusyan, dkk. 1989). Dengan demikian, dianggap bahwa instrumen penelitian ini termasuk valid.

Selanjutnya, untuk uji reliabilitas butir soal dalam penelitian ini digunakan metode belah dua (Split-Half Method) dengan skor ganjil dan skor genap, dengan rumus Spearman Brown, pada Tabel 1.

Tabel 1. Uji Reliabilitas Instrumen Penelitian

\begin{tabular}{ccc}
\hline $\begin{array}{c}\text { Cronbach's } \\
\text { Alpha }\end{array}$ & $\begin{array}{c}\text { Cronbach's Alpha } \\
\text { Based on } \\
\text { Standardized Items }\end{array}$ & $\begin{array}{c}\mathrm{N} \text { of } \\
\text { Items }\end{array}$ \\
\hline .949 & .952 & 2 \\
\hline
\end{tabular}

Hasil analisis dengan rumus Spearman Brown menunjukkan bahwa hasil uji coba tes ini memiliki reliabilitas 0,949. Dari hasil sebesar ini, instrumen ini dapat digunakan dalam penelitian yang sesunguhnya. Bilangan yang menunjukkan sukar dan mudahnya suatu soal adalah indeks kesukaran. Rumus digunakan untuk untuk pengujian tingkat kesukaran setiap butir.

Terdapat 28 butir soal yang telah diujicoba validitas dan reliabilitasnya. Butir-butir soal ini kemudian dianalisis per butir. Hasil analisis digunakan untuk memilih soal yang baik dan memenuhi syarat digunakan untuk mengambil data. Dari 28 butir soal yang diujicobakan pada mahasiswa dengan $n=22$, ternyata bahwa delapan di antaranya tidak dapat dipakai, karena setelah perhitungan tingkat kesukaran masing-masing butir soal, lima di antaranya tergolong sangat sukar. Tingkat kesukaran (TK) soal-soal tersebut berkisar antara $0,000-0,300$. Sebaliknya, tiga lainnya tergolong terlalu mudah, yakni tingkat kesukarannya berkisar antara $0,701-1,000$. Dengan demikian, dari hasil uji coba instrumen yang memenuhi syarat adalah sebanyak 20 butir soal.

Penelitian ini menggunakan desain kelompok tunggal dengan Pre-test, yakni tes yang 
dilakukan sebelum diadakan perlakuan dengan model pembelajaran kooperatif tipe TAPPS, dan post-test, yang dilakukan setelah diadakan perlakuan dengan model pembelajaran kooperatif tipe TAPPS. Pelaksanaannya dilakukan sebagai berikut: Awalnya, materi perkuliahan dijelaskan kepada mahasiswa tanpa menggunakan langkahlangkah model pembelajaran kooperatif tipe TAPPS. Setelah itu dosen memberikan tes tertulis kepada mahasiswa dan hasilnya diberi nilai yang sesuai dengan komponen-komponen penilaian yang ada (Pretest). Selanjutnya, materi pelajaran diberikan kepada mahasiswa dengan menggunakan langkah-langkah model pembelajaran kooperatif tipe TAPPS, dan akhirnya dosen kembali memberikan tes tertulis dan hasilnya diberi nilai sesuai dengan komponen-komponen penilaian yang ada (Post-test).

Data hasil penelitian ini akan dianalisis dengan menggunakan uji beda (uji t) dengan bantuan SPSS-18, dengan kriteria; jika $t_{\text {hitung }>} t_{\text {tabel}}$, maka dapat dikatakan bahwa ada perbedaan yang signifikan (berarti).

\section{HASIL DAN PEMBAHASAN Hasil}

Telah dijelaskan sebelumnya bahwa tujuan penelitian ini adalah untuk mengetahui pengaruh model pembelajaran kooperatif tipe TAPPS terhadap hasil belajar Strukturen und Wortschatz 2 mahasiswa Program Studi Pendidikan Bahasa Jerman. Dengan demikian, data yang akan dideskripsikan dalam bagian ini adalah data hasil belajar Strukturen und Wortschatz 2 mahasiswa sebelum dan setelah aplikasi model pembelajaran kooperatif tipe TAPPS untuk mahasiswa yang dijadikan sebagai sampel. Selanjutnya, untuk membuktikan hipotesis dari data tersebut akan diolah dengan menggunakan analisis uji beda dengan program SPSS- 18 .

Dari hasil pretes hasil belajar Strukturen und Wortschatz 2, nilai yang dicapai oleh mahasiswa sebelum penerapan model pembelajaran kooperatif tipe TAPPS adalah: nilai 80 sebanyak 4 orang; nilai 75 sebanyak 5 orang; nilai 70 sebanyak 6 orang; nilai 60 sebanyak 7 orang; dan nilai 50 sebanyak 10 orang, dengan nilai rata-rata pada kelompok eksperimen $\left(\mathrm{X}_{2}\right)$ sebesar 80,0 dan kelas kontrol $\left(\mathrm{X}_{1}\right)$ sebesar 60,0. Hasilnya dapat dilihat pada Tabel 1 .
Tabel 2. Analisis Deskriptif pada Kedua Kelompok

\begin{tabular}{lrr}
\hline & \multicolumn{1}{c}{$\mathrm{X}_{1}$} & \multicolumn{1}{c}{$\mathrm{X}_{2}$} \\
\hline N Valid & 32 & 32 \\
$\quad$ Missing & 0 & 0 \\
Mean & 63.5938 & 76.8750 \\
Median & 60.0000 & 80.0000 \\
Mode & 50.00 & $70.00^{\mathrm{a}}$ \\
Std. Deviation & 11.23319 & 9.97982 \\
Variance & 126.184 & 99.597 \\
Range & 30.00 & 30.00 \\
Minimum & 50.00 & 60.00 \\
Maximum & 80.00 & 90.00 \\
Sum & 2035.00 & 2460.00 \\
\hline
\end{tabular}

Hasil belajar posttest Strukturen und Wortschatz 2 sesudah perlakuan pada kedua kelompok, dimana kelompok aplikasi model konvensional dan model kooperatif tipe TAPPS, dapat dikatakan bahwa kelompok kelas eksperimen memiliki nilai (hasil belajar) Bahasa Jerman lebih baik, jika dibandingkan dengan kelas kontrol. Hasil ini didukung dengan data pada Tabel 2, menunjukkan bahwa nilai tertinggi yang diperoleh kelompok mahasiswa pada kelas eksperimen $\left(\mathrm{X}_{2}\right)$ adalah 90 sebanyak 8 orang, sedangkan nilai terendah yang dicapai adalah 60 sebanyak 4 orang dari nilai maksimal yaitu 100 dengan rata-rata sebesar 76,8.

\section{Pengujian hipotesis}

Hipotesis penelitian ini berbunyi: Ada pengaruh penerapan model pembelajaran kooperatif tipe TAPPS terhadap hasil belajar Strukturen und Wortschatz 2 mahasiswa Program Studi Pendidikan Bahasa Jerman sebelum dan sesudah menggunakan model pembelajaran kooperatif tipe TAPPS. Untuk pembuktian hipotesis penelitian ini digunakan analisis uji-t, hasilnya dapat dilihat pada Tabel 3.

Jika dibandingkan nilai hasil belajar Struktuen und Wortschatz 2 mahasiswa Program Studi Bahasa Jerman yang diajar dengan menerapkan model pembelajaran kooperatif tipe TAPPS dan model konvensional dengan nilai hasil belajar Strukturen und Wortschatz 2, terlihat bahwa nilai hasil belajar Strukturen und Wortschatz 2 mahasiswa bahasa Jerman yang diajar dengan menggunakan model pembelajaran kooperatif tipe TAPPS lebih tinggi dibandingkan dengan nilai hasil belajar Strukturen und Wortschatz 2 mahasiswa Program Studi Pendidikan Bahasa Jerman yang diajarkan dengan model konvensional. Hasil 
Tabel 3. Uji Beda antar Dua Variabel

\begin{tabular}{rrrrrrr}
\hline & & & \multicolumn{2}{c}{ Test Value $=0$} & \multicolumn{2}{c}{ 95\% Confidence Interval of the } \\
& & & & Mean & \multicolumn{2}{c}{ Difference } \\
& $\mathrm{t}$ & Df & Sig. (2-tailed) & Difference & Lower & Upper \\
\hline $\mathrm{X}_{1}$ & 32.025 & 31 & .000 & 63.59375 & 59.5438 & 67.6437 \\
$\mathrm{X}_{2}$ & 43.575 & 31 & .000 & 76.87500 & 73.2769 & 80.4731 \\
\hline
\end{tabular}

ini dapat dibuktikan dengan nilai yang diperoleh dari hasil perhitungan rata-rata yang diperoleh pada kedua kelas, yakni, nilai tertinggi kelas $X_{1}$ sebesar 67,64, terendah sebesar 59,54, sedangkan kelas $\mathrm{X}_{2}$ nilai tertinggi sebesar 80,47 dan terendah sebesar 73,28.

\section{Pembahasan}

Hasil penelitian menunjukkan bahwa model pembelajaran kooperatif tipe TAPPS memiliki dampak positif dalam meningkatkan hasil belajar mahasiswa. Hal ini dapat dilihat dari semakin mantapnya pemahaman mahasiswa terhadap materi yang disampaikan dosen. Hasil ini disebabkan karena dalam penerapan model pembelajaran kooperatif tipe TAPPS dalam pembelajaran Strukturen und Wortschatz 2, mahasiswa saling mendorong untuk belajar, saling memperkuat upaya-upaya akademik dan menerapkan norma yang menunjang pencapaian hasil belajar yang tinggi (Nur, 1996:4). Pembelajaran kooperatif lebih mengutamakan sikap sosial untuk mencapai tujuan pembelajaran yaitu dengan cara kerjasama. Dikatakan bahwa dalam pembelajaran kooperatif mahasiswa tidak hanya sebagai objek belajar tetapi menjadi subjek belajar karena mereka dapat berkreasi secara maksimal dalam proses pembelajaran. Hal ini terjadi karena pembelajaran kooperatif merupakan metode alternatif dalam mendekati permasalahan yang memampukan mahasiswa mengerjakan tugas, meningkatkan keterampilan komunikasi dan sosial, serta memperoleh kepercayaan diri.

Selain itu dalam menyampaikan pikiran dan perasaan, mahasiswa menjadi lebih yakin dalam mengungkapkannya sebab ada unsur keterbukaan. Dengan sendirinya penerapan model pembelajaran kooperatif tipe TAPPS juga telah menciptakan komunikasi aktif antar mahasiswa. Penggunaan model pembelajaran kooperatif tipe TAPPS membantu mengurangi atau menghilangkan kebosanan mahasiswa dalam belajar yang tentunya memberikan kontribusi positif bagi mahasiswa, sehingga dapat meningkatkan hasil
Strukturen und Wortschatz 2 mereka. Sebaliknya dengan pengajaran sebelum menggunakan Model pembelajaran kooperatif tipe TAPPS hasil belajar yang dicapai oleh mahasiswa sangat rendah. Hal ini disebabkan karena sebelumnya metode yang dipakai oleh dosen kurang bervariasi atau monoton, sehingga mengakibatkan mahasiswa merasa bosan dan tidak tertarik dengan pelajaran yang diberikan serta kurang termotivasi untuk belajar. Dengan penerapaan model pembelajaran kooperatif tipe TAPPS, motivasi belajar mahasiswa meningkat, yang diikuti dengan peningkatan hasil belajar Strukturen und Wortschatz 2 sebagai bukti bahwa model pembelajaran kooperatif tipe TAPPS memberikan pengaruh yang signifikan terhadap hasil belajar Strukturen und Wortschatz 2 mahasiswa Program Studi Pendidikan Bahasa Jerman FKIP Universitas Pattimura.

Hasil yang diperoleh dapat dikatakan baik, karena model ini memiliki kelebihan-kelebihan dalam proses perkuliahan, dimana mahasiswa dapat menyelesaikan permasalahan yang mereka jumpai secara berpasangan, dengan satu anggota pasangan berfungsi sebagai pemecah permasalahan dan yang lainnya sebagai pendengar. Pemecah permasalahan menyampaikan semua pemikiran mereka saat mereka mencari sebuah solusi, pendengar mendorong rekan mereka untuk tetap untuk berbicara dan menawarkan anggapan umum atau petunjuk jika bagian pemecah masalah tertekan.

Felder (1994:6-8) menyatakan bahwa dalam memberikan saran dalam membentuk kelompok pembelajaran kooperatif tipe TAPPS, harus dilakukan dengan beberapa cara, yaitu sebagai berikut. 1) Berikan tugas kelompok yang terdiri atas tiga sampai empat mahasiswa. 2) Saat mahasiswa bekerja terpisah, salah satu di antaranya lebih mendominasi dan biasanya bukanlah mekanisme yang baik untuk memecahkan perdebatan, dan dalam tim yang berisi lima orang atau lebih akan menjadi sulit untuk mempertahankan keterlibatan setiap orang dalam proses. Kumpulkan satu tugas per kelompok. 3) Usahakan membentuk 
kelompok yang kemampuannya heterogen. Hambatan akan dijumpai jika satu kelompok memiliki anggota yang semuanya lemah akan tampak nyata tetapi dengan mengumpulkan satu kelompok yang memiliki anggota dengan kemampuan kuat juga tidak disarankan. 4) Hindari kelompok di mana mahasiswa perempuan dan mahasiswa minoritas yang banyak jumlahnya. Studi-studi telah memperlihatkan bahwa gagasan mahasiswa perempuan dan kontribusinya seringkali dikurangi atau dipotong dalam tim yang memiliki kelompok berjenis kelamin campuran, dan para mahasiswa perempuan akhirnya mengambil peran pasif dalam interaksi kelompok. Jika sangat memungkinkan, memilih kelompok sendiri. Dalam membentuk kelompok, mahasiswa menentukan sendiri anggota kelompoknya. 5) Pemberian tugas regu dengan masing-masing tugas yang berputar.

Dalam kelompok menghendaki perputaran tugas. Tugas-tugas dalam kelompok yaitu: (1) koordinator (mengorganisir tugas ke dalam sub tugas, mengalokasikan tanggung jawab, mempertahankan kelompok tetap berorientasi pada tugas); (2) pemeriksa (memonitor kedua solusi dan pemahaman tiap-tiap anggota regu di antara mereka); (3) perekam (melihat kemungkinan konsensus, menulis solusi kelompok yang lahir); (4) skeptis (menyarankan berbagai kemungkinan alternatif, menghindari kelompok melompat pada kesimpulan terlalu awal); 5) mempertimbangkan hal positif yang saling bergantung. Semua anggota regu perlu merasakan bahwa mereka mempunyai peran unik untuk berperan serta di salah satu kelompok dan tugas hanya dapat diselesaikan dengan baik jika semua anggota melakukan tugas mereka; 7) mempertimbangkan tanggung jawab individu. Cara terbaik untuk mencapai tujuan adalah dengan memberikan tes individu, selain itu dalam pemilihan anggota regu perlu menjelaskan hasil regu itu; 8) membuat kelompok secara teratur menilai prestasi mereka. Pada awal tugas, mahasiswa perlu mendiskusikan apa yang sebaiknya dikerjakan, kesulitan apa yang muncul, dan apa yang tiap-tiap angggota dapat lakukan untuk membuat semua hal bekerja lebih baik; 9) menawarkan gagasan agar kelompok berfungsi efektif. Suatu pendekatan untuk menyiapkan mahasiswa dengan beberapa unsur-unsur arahan yang akan menghasilkan suatu pernghargaan dari apa sebenarnya kerja kelompok dan untuk membantu pengembangan dari keterampilan hubungan antarpribadi yang menopang di dalam pembentukan regu dan prestasi; 10) menyediakan bantuan regu yang memiliki kesukaran dalam bekerja sama. Kelompok yang mempunyai permasalahan harus dipertemukan dengan pengajar untuk mendiskusikan kemungkinan pemecahan masalah; dan 11) jangan membentuk kembali kelompok yang sudah pernah terbentuk.

Tujuan bekerjasama yang utama akan membantu para mahasiswa memperluas daftar literatur pendekatan pemecahan masalah mereka, dan tujuan kedua akan membantu mereka mengembangkan keterampilan kepemimpinan kolaboratif, pengambilan keputusan dan tujuan lainnya. Ini hanya dapat dicapai jika para mahasiswa mempunyai cukup waktu untuk mengembangkan suatu dinamika kelompok, persaingan dan menanggulangi berbagai kesulitan dalam bekerja bersamasama, dimana dalam kaitan dengan penjelasan ini, maka dapat dikatakan bahwa pembelajaran kooperatif tipe TAPPS merupakan suatu model pembelajaran dengan cara mengelompokkan mahasiswa ke dalam kelompok-kelompok kecil untuk bekerja sama dalam memecahkan masalah. Kemampuan mahasiswa dalam setiap kelompok adalah heterogen.

Pembelajaran Strukturen und Wortschatz adalah proses belajar yang dilakukan dalam upaya memberikan kesempatan kepada mahasiswa untuk memahami dan menguasai, kaidah-kaidah gramatika atau tata bahasa bahasa Jerman serta mempraktekkannya dalam situasi nyata. Khusus untuk Strukturen und Wortschatz 2, materi-materi pembelajaran meliputi: (1) Nebensätze mit weil, dass, (2), Komparation mit wie und als (3) Reflexivpronomen, (4) Verben mit Präpositionen, (5) Indirekte Fragen im Nebensatz: ob-Sätze / indirekte W-Fragen, Adjektive im Nominativ und Akkusativ, (6) Personalpronomen im Dativ: mit dir, mit ihm, (7) Relativsatz, Relativpronomen im Nominativ und Akkusativ, (8) Modalverben im Präteritum, (9) Zeitadverbien: damals, früher, heute, jetzt, (10) Verben im Präteritum, (11) Verben im Perfekt, (12) Nominalisierung, (13) Wechselpräpositionen, und (14) Nebensätze mit um - zu/damit (Funk dkk, 2008:8-192).

Melalui pembelajaran Strukturen und Wortschatz bahasa Jerman mahasiswa diharapkan mampu belajar grammatik bahasa Jerman dengan berbagai cara yang sangat bermakna, seperti belajar secara sistematis dengan langkah-langkah penyajian yang bervariasi untuk membangkitkan minat dan motivasi mahasiswa, baik dalam bentuk 
permainan, maupun dengan dialog-dialog, dan diikuti dengan kerjasama antarmahasiswa maupun kelompok mahasiswa yang membangun, sehingga memperoleh hasil pembelajaran yang efektif dan bermutu dapat diperoleh (Frangou dkk, 2014).

Bila dikaitkan dengan hasil-hasil penelitian lainnya yang relevan, maka hasil penelitian di atas tidak berbeda. Misalnya, hasil penelitian tindakan kelas yang dilakukan oleh Rohaeti, Suwardi, dan Ikhsan, tentang peningkatan prestasi dan kemandirian belajar mahasiswa melalui pendekatan reciprocal teaching dan cooperative learning dengan subjek penelitian adalah mahasiswa Program Studi Pendidikan Kimia FMIPA Universitas Negeri Yogyakarta yang menempuh mata kuliah Kimia Fisika II. Hasil penelitian ini menunjukkan bahwa setelah mengikuti perkuliahan, terdapat $92,31 \%$ mahasiswa yang mencapai ketuntasan belajar secara individual. Kemandirian mahasiswa dalam belajar juga meningkat. Mahasiswa menunjukkan tanggapan positif dan antusiasme terhadap perkuliahan.

Hasil penelitian ini relevan juga dengan penelitian Johnson (1999), yaitu; The Effect of Thinking Aloud Pair Problem Solving (TAPPS) on the Troubleshooting Ability of Aviation Technician Students, dengan hasil sebagai berikut. There was a significant difference in the ability of the TAPPS group $(\mathrm{M}=4.00, \mathrm{SD}=0)$ and the TTT group $(\mathrm{M}=3.61, \mathrm{SD}=.50)$ to recognize that four faults existed in the electrical system, $\mathrm{t}$ $(26)=2.431, p<.05$. Eleven of the eighteen TTT group subjects recognized all four faults, while seven (39\%) failed to notice that the landing gear circuit was faulty. The inability of TTT subjects to recognize the fault in the gear indicator subsystem is likely due to the fact that the subjects' initial problem finding activity focused on the operation of the control panel switches and the gear indicator does not have a switch on the control panel. Overall, the TTT group recognized $90 \%$ of the faults. All of the TAPPS subjects recognized that there were four faults in the electrical system $(100 \%)$. This difference was unexpected because the TTT did not require the subjects to engage in problem finding activity. At the start of each scenario, the Tutor group subjects knew that a fault existed and the symptomatic information that was available on request provided sufficient clues to narrow the fault down to a specific subsystem (Journal of Industrial Teacher Education, Vol. 37, Number 1, 1999).
Hal yang sama juga yang dilakukan oleh Maula, Rochmad, dan Soedjoko, yang meneliti tentang Keefektifan Pembelajaran Model TAPPS Berbantuan Worksheet terhadap Kemampuan Pemecahan Masalah, hasil penelitian menunjukkan bahwa rata-rata kemampuan pemecahan masalah siswa kelas eksperimen lebih tinggi daripada kelas kontrol. Dari hasil uji proporsi satu pihak, diperoleh persentase ketuntasan belajar siswa kelas eksperimen lebih tinggi daripada pada kelas kontrol. Simpulan yang diperoleh yaitu pembelajaran dengan model TAPPS menunjukkan bahwa, rata-rata kemampuan pemecahan masalah siswa pada model TAPPS lebih tinggi daripada rata-rata kemampuan pemecahan masalah siswa pada pembelajaran ekspositori, dan persentase ketuntasan belajar siswa pada model TAPPS lebih tinggi daripada persentase ketuntasan belajar siswa pada pembelajaran ekspositori.

Ada juga penelitian yang dilakukan oleh Nimas, dkk tentang: Penerapan Pembelajaran Kooperatif dengan Metode Thinking Aloud Pair Problem Solving (TAPPS) untuk Meningkatkan Aktivitas dan Hasil Belajar siswa, diperoleh hasil persentase aktivitas guru pada siklus I sebesar $89,38 \%$, sedangkan pada siklus II aktivitas guru mencapai persentase sebesar $95,45 \%$; persentase aktivitas siswa pada siklus I sebesar 70,78\% dan pada siklus II sebesar 81,54\%; sedangkan persentase hasil belajar siswa secara klasikal pada siklus I sebesar 70,27 \% dan pada siklus II sebesar 78,37\%.

Hal yang sama juga yang dilakukan oleh Haryati (2016), tentang Penerapan Model Pembelajaran Thinking Aloud Pair Problem Solving (TAPPS) untuk Meningkatkan Kemampuan Pemecahan Masalah, diperoleh hasil bahwa adanya peningkatan kemampuan pemecahan masalah matematis siswa SMA yang mendapatkan model pembelajaran Thinking Aloud Pair Problem Solving (TAPPS) lebih tinggi daripada siswa SMA yang mendapatkan model pembelajaran Problem Based Learning (PBL); siswa bersikap positif terhadap penggunaan model pembelajaran Thinking Aloud Pair Problem Solving (TAPPS) dalam pembelajaran matematika. Oleh karena itu model pembelajaran Thinking Aloud Pair Problem Solving (TAPPS) dapat dijadikan suatu alternatif bagi guru dalam melaksanakan pembelajaran untuk meningkatkan kemampuan pemecahan masalah dan menciptakan sikap yang positif 
Selanjutnya, penelitian lain dilakukan oleh Ramadhani (2017) dengan judul Efektivitas Penerapan Model Pembelajaran Thinking Aloud Pair Problem Solving (TAPPS) terhadap Kemampuan Metakognisi dan Hasil Belajar, diperoleh hasil uji korelasi linier sederhana dengan nilai regresi sebesar 0,36 yang menunjukkan besaran pengaruh kemampuan metakognisi terhadap hasil belajar, sedangkan nilai $r=0,332$ menunjukkan bahwa ada korelasi langsung atau korelasi positif antara kemampuan metakognisi dan hasil belajar.

Kesamaan penelitian ini dengan penelitianpenelitian relevan yang dikemukakan di atas, terletak pada penerapan metode pembelajaran Kooperatif model TAPPS (variabel pengaruh) untuk peningkatan hasil belajar baik siswa maupun mahasiswa, di mana semua penelitian melakukan hal yang sama. Perbedaan penelitian ini dengan penelitian-penelitian relevan terletak pada bidang kajian, di mana penelitian-penelitian relevan umumnya mengkaji bidang ilmu eksakta, sedangkan penelitian ini mengkaji bidang ilmu kebahasaan (Strukturen Und Wortschatz bahasa Jerman).

Dalam kaitan dengan hasil-hasil penelitian yang relevan di atas, maka dapat dikatakan bahwa hasil penelitian tentang penerapan metode pembelajaran Kooperatif Model TAPPS dan pengaruhnya yang signifikan terhadap peningkatan hasil belajar Strukturen Und Wortschatz 2 Mahasiswa Program Studi Pendidikan Bahasa Jerman Fakultas Keguruan dan Ilmu Pendidikan Universitas Pattimura Ambon dan kajian penelitian yang relevan tentang penerapan model pembelajaran TAPPS yang secara umum memberikan pengaruh yang signifikan terhadap hasil belajar mata pelajaran-mata pelajaran lain yang dikemukakan di atas, mengisyaratkan tentang pentingnya menjaga keberlangsungan penerapan model pembelajaran TAPPS dalam kegiatan belajar mengajar mata pelajaran lain.

Dengan demikian, berdasarkan hasil penelitian yang diperoleh menggambarkan bahwa hasil belajar mahasiswa bahasa Jerman FKIP Universitas Pattimura memiliki hasil yang sangat baik dengan menerapakan model pembelajaran kooperatif tipe TAPPS, jika dibandingkan dengan pembelajaran dengan menerapakan model konvensional. Hasil ini terlihat dalam perkuliahan materi Strukturen Und Wortschatz 2, dimana aktivitas dan respon mahasiswa bahasa Jerman itu positif dan bersemangat dalam mengikuti perkuliahan. Keaktifan mahasiswa ini dapat ditunjuk- kan dalam perkuliahan, dimana dapat mengimplementasikan komunikasi aktif dengan temannya, dan mahasiswa bahasa Jerman dapat menguasai materi pelajaran dengan mudah karena mahasiswa lebih mudah memahami penjelasan teman-teman bila dibandingkan dengan penjelasan dari dosen karena taraf pengetahuan serta pemikiran mereka lebih sejalan dan sepadan.

\section{SIMPULAN}

Dari hasil penelitian yang telah dilakukan, dan berdasarkan deskripsi data, hasil analisis data, serta seluruh pembahasan yang telah dilakukan dapat disimpulkan sebagai berikut.

1. Pembelajaran kooperatif model TAPPS memiliki dampak positif dalam meningkatkan hasil belajar Strukturen und Wortschatz 2 mahasiswa tampak pada peningkatan prestasi belajar mahasiswa bahasa Jerman.

2. Penerapan model pembelajaran kooperatif tipe TAPPS memunyai pengaruh positif, yaitu dapat meningkatkan motivasi belajar mahasiswa yang ditunjukan dengan hasil wawancara dengan beberapa mahasiswa, yang rata-rata menyatakan bahwa ketertarikan dan minat terhadap metode pembelajaran kooperatif model TAPPS yang membuat mereka termotivasi untuk belajar bahasa Jerman.

\section{UCAPAN TERIMA KASIH}

Penulis ingin menyampaikan terima kasih kepada Dekan FKIP Universitas Pattimura, dan Bpk/Ibu Dosen Program Studi Pendidikan Bahasa Jerman FKIP Unpatti yang telah memberikan bantuan dana penelitian kolaborasi, dan banyak meluangkan waktu untuk mengarahkan dan membantu peneliti dalam proses pengambilan data sampai kepada pengolahan data, sehingga penelitian ini dapat berjalan dengan baik. Ucapan terima kasih juga, penulis sampaikan kepada dewan redaksi Jurnal Cakrawala Pendidikan yang dengan teliti memeriksa tulisan saya dengan saran perbaikan, proses review dan memberikan kesempatan kepada penulis untuk penerbitan tulisan ini.

\section{DAFTAR PUSTKA}

Bungin, Burhan. 2008. Metodologi Penelitian Kuantitatif (Komunikasi, Ekonomi, dan Kebijakan Publik serta Ilmu-ilmu Sosial Lainnya. Jakarta: Kencana Prenada Media Group. 
Felder, Richard M. 1994. Cooperative Learning in Technical Corse, (online), (Pcll $\backslash \mathrm{d} \backslash \mathrm{My} \%$ Document $\backslash$ Coop \% 20 Report: 2, 5, 6-8.

Frangou, Eleni, Kokkini, Eva und Petrowa, Amalia. 2014. Schritt Für Schritt Ins Grammatiksland. München: Max Hueber Verlag: 7.

Funk, Hermann, Kuhn Christina, Demme, Silke und Winzer, Britta. 2008. Studio d A2 (Deutsch als Fremdsprache: Kurs- und Übungsbuch). Jakarta: Katalis: 8-192.

Haryati, Tati. 2016. Penerapan Model Pembelajaran Thinking Aloud Pair Problem Solving (TAPPS) untuk Meningkatkan Kemampuan Pemecahan Masalah Matematis pada Siswa SMA PGRI 1 Subang tahun ajaran 2015-2016. http://repository.unpas. ac.id/10346/3/.

Johnson, Scott D. and Shih-Ping Chung. 1999. The Effect of Thinking Aloud Pair Problem Solving (TAPPS) on the Troubleshooting Ability of Aviation Technician Students. (Journal of Industrial Teacher Education, Vol. 37(1).

KBBI. 1996. Edisi Kedua. Jakarta: Balai Pustaka: 14.

Maula, Nikmatul, Rochmad, dan Edy Soedjoko, 2013. Keefektifan Pembelajaran Model TAPPS Berbantuan Worksheet Terhadap Kemampuan Pemecahan Masalah Materi Lingkaran pada siswa kelas VIII SMP N 2 Pekalongan tahun pelajaran 2012/2013, Journal of Mathematics Education, Vol. $2(1)$.
Megawangi, Ratna, Latifah, Melly, \& Dina, Farrah Wahyu. 2005, Pendidikan Holistik (Aplikasi Kurikulum Berbasis Kompetensi (Kurikulum 2004) Untuk Menciptakan Lifelong Learners), Jakarta: Indonesia Heritage Foundation: 41, 43, 67.

Mustikawati, Nimas Ayu; Susanto; NurcholifDiah Sri Lestari. 2015. Penerapan Pembelajaran Kooperatif dengan Metode Thinking Aloud Pair Problem Solving (TAPPS) untuk Meningkatkan Aktivitas dan Hasil Siswa Kelas VII B SMPN 11 Jember Tahun Ajaran 2014/2015 pada Sub Pokok Bahasan Operasi Himpunan URI: http://repository. unej.ac.id/handle/123456789/63769.

Nur, Muhammad. 1996. Pembelajaran Kooperatif. Surabaya: Universitas Negeri Surabaya: $2,4$.

Ramadhani, Diah. 2017. Semarang: Efektivitas Penerapan Model Pembelajaran Thinking Aloud Pair Problem Solving (TAPPS) Terhadap Kemampuan Metakognisi Dan Hasil Belajar Pada Materi Lingkaran Kelas VIII SMP Negeri 2 Subah Batang.

Rohaeti, Eli, Suwardi, dan Jaslin Ikhsan. 2013. "Peningkatan Prestasi Dan Kemandirian Belajar Mahasiswa Melalui Pendekatan Reciprocal Teaching Dan Cooperative Learning,", Cakrawala Pendidikan, Tahun XXXII (1).

Tilaar, H.A.R., 2006. "Standarisasi Pendidikan Nasional (Suatu Tinjauan Kritis)". Jakarta: Rineka Cipta.

Wahyuni, Dwi. 2004. "Studi tentang Pembelajaran Kooperatif terhadap Hasil Belajar Matematika". Malang: Program Sarjana Universitas Negeri Malang: 2,8,10. 